\title{
François Hollandes afrikanske eventyr
}

\section{Erling Bjøl og Denise Séheux}

\section{"Afrikas fremtid skal bygges på en styrkelse af afrikanernes evne til at styre deres egne kriser", har den franske præsident sagt i bevidsthed om, at fremmede soldater, selv om de kommer som befriere efter tre måneder begynder at blive betragtet som besættere}

Afrika stod ikke øverst på François Hollandes problemliste, da han sidste sommer blev valgt til præsident. Men allerede den 26. september kunne han i FN's åbningsdebat gøre opmærksom på, at der var ved at opstå en farlig situation i den nordlige del af Mali. Det var ved at udvikle sig til et tilflugts- og afsatsområde for den internationale terrorisme.

"Det, der sker i den nordlige del af Mali, er ikke bare en udfordring for dette lands myndigheder. Det er en trussel mod Vestafrika og Maghreb", sagde han. "Det indebærer også en risiko for hele det internationale samfund. For når et område på størrelse med Frankrig bliver besat af terroristgrupper, som ikke bare har sat sig for at kontrollere en be- folkning, at straffe og underkue den, men at oprette en afsætningsbase for terroristangreb mod regionens stater, står vi over for en trussel, som angår hele menneskeheden."

Der var flere grunde til, at Mali kunne blive særlig farligt som terroristisk baseområde. Først geografiske med landets centrale beliggenhed. Det grænser op til ikke mindre end syv lande: Algeriet, Niger, Burkina Faso, Guinea, Elfenbenskysten, Senegal og Mauretanien. Dertil kommer politiske forhold, som har gjort det nordlige grænseland særlig svært at kontrollere: Konflikten mellem Marokko og Algeriet om et stykke grænseland, som har udelukket samarbejde mellem de to Maghrebstater, siden Algeriet blev selvstæn- 
digt, efterfulgt af den langvarige borgerkrig i Algeriet. Valget i december 1991 førte til en sejr for det islamistiske parti Front Islamique du Salut (FIS), som FLN-regimet ikke ville affinde sig med.

Krigen varede i ti år. Antallet af dræbte er ifølge François Hollande blevet anslået til op imod 200.000. Islamisterne tog derefter tilflugt i de uvejsomme kratskove og klippebjerge i Kabylien og Ifoghas i grænseområdet mellem Algeriet og Nordmali. De dannede en fællesorganisation AQIM (Al-Quaida au Maghreb Islamiste). Men der opstod efterhånden mere eller mindre selvstændige terroristgrupper, som gav sig af med gidselstagninger, attentater, våbenhandler, narkosmuglinger og bagholdsangreb. De mest frygtede var terroristhøvdingerne Abou Zeid og Mokhtar Belmokhtar.

\section{Gaddafis rolle}

Islamisterne fik forstærkninger i mænd, våben, køretøjer og materiel, efter at præsident Sarkozy, ivrigt tilskyndet af de nye filosoffers førende talsmand Bernard-Henri Lévy, i foråret 2011 havde besluttet at standse Libyens diktator oberst Gaddafi, da denne ville knuse et oprør i Benghazi, der var udsprunget af det arabiske forår, som begyndte i Tunesien i december 2010. Gaddafi havde med sine mange oliepenge anskaffet sig rigelige forsyninger af moderne våben og materiel. Han havde også hyret soldater fra andre dele af Afrika, ikke mindst fra Mali. Da han blev fældet, vendte de hjem og tog våben og udstyr med sig, som de kunne få afsat til de forskellige terroristgrupper i Nordmali.

Foruden de religiøst motiverede var der tuaregerne, som flere gange havde gjort oprør mod at blive styret fra 'Krokodillemosen', som Bamako egentlig betyder, i syd. Efterhånden fik AQIM kontrol med den nordlige del af Mali, inklusive byerne, og indførte sharialovgivning, der forbød alskens forlystelser samt tvang kvinderne til at gå med slør og truede dem med at blive stenet ihjel, hvis de er utro.

Imidlertid gik staten Mali mere og mere i opløsning. I november 2009 var en Boeing 727 nødlandet i nærheden af Gao i Nordmali med mellem fem og ni tons kokain fra Venezuela. Denne last forsvandt sporløst, og flyet blev brændt. En libanesisk familie og en mauretansk forretningsmand har været nævnt blandt aftagerne. Men fra da af fandt de internationale narkobaroner, at det var mere sikkert at bruge søvejen fra Latinamerika og derpå Niger Floden op igennem Mali, til man nåede karavanevejene i nord og det videre transportnet til Europa og Mellemøsten.

For at sikre denne rute, bestak man ledende generaler og efterretningsfolk i Malis hær og deres politiske chefer eller marionetter. Nogle af dem kunne ikke dy sig for at prale 
med deres nye velstand ved at anskaffe sig en park af luksusbiler, som 'hele Malis forsvarsbudget' ifølge $L e$ Monde Diplomatique ikke ville have været i stand til at betale. Det blev for meget for nogle yngre officerer, der i marts 2012 under ledelse af en kaptajn Sanogo greb magten i Bamako.

\section{Præsidentens flugt}

Præsidenten flygtede ud af landet. Hans post blev i overensstemmelse med forfatningen midlertidigt overtaget af parlamentsformand Dioncounda Traoré. Premierministerposten blev overdraget den ansete videnskabsmand Cheick Modibo Diarra fra NASA. Men kaptajn Sanogo bestemte, hvem der kunne være med i overgangsregeringen.

52 generaler blev efterhånden fyret. Af Malis hær var der ikke meget tilbage.

Hele den udvikling foruroligede landene i den vestafrikanske samarbejdsorganisation CEDEAO (Communauté Economique des Etats de l'Afrique de l'Ouest). Ni af dem (Tchad, Togo, Benin, Senegal, Niger, Guinea, Burkina Faso, Nigeria og Ghana) besluttede i foråret 2012 at danne en Mission Internationale de Soutien au Mali (MISMA), der skulle råde over et korps på 6.000 mand under ledelse af en nigeriansk general. Franske officerer blev tilkaldt for at deltage i planlægningen.

Selv om den ikke længere havde nogen demokratisk regering, var der et livligt kulturliv i Bamako, der ligefrem er blevet kaldt 'Afrikas kulturelle hovedstad' (Le Point).

Mens islamisterne indførte deres missionske shariabestemmelser i Nordmali og fik det arabiske forår til at visne i Ægypten og selv Tunesien, blev der afholdt filmfestival i Burkina Faso, hvor en af priserne gik til en tunesisk film om kvindens kår, som blev forbudt i Tunesien. Og fransksprogede forfattere mødtes i Brazzaville for at diskutere strømningerne inden for den frodige afrikanske litteratur. Men i musiklivet var ingen by mere sprælsk end Bamako. Byen havde både et universitet og en kunsthåndværkerskole og kunstnere, der gav sig af med noget så syndigt som at male og videreføre de store afrikanske traditioner i skulpturer, der havde fascineret Montparnasse før 1914. Blandt de malerier, der kom frem, var der et, som var vendt direkte mod shariaensretningen i Nord.

Tre religioner levede relativt fredsommeligt side om side, og man regner med, at der var 13 forskellige folkeslag i byen. Malis udenrigsminister kaldte sit land en 'mosaik af mindretal'. Det sorte Afrikas ufatteligt brogede etniske og sproglige mangfoldighed har skabt et helt andet behov for et fællessprog som fransk end i det homogene arabiske Nordafrika.

Af de 30.000 franske borgere, der boede i Vest- og Ækvatorialafrika, 
havde 6.000 slået sig ned i Bamako.

Der var mange grunde til, at byen måtte anses for et syndens Sodoma og Gomorra af islamisterne i nord, der ønskede at få kontrol med Bamako. Dertil kom narkobaronernes interesse i Niger Floden.

Det var en tung arv, François Hollande kom til at overtage efter Sarkozy og Chirac. Af de fransksprogede lande i CEDEAO havde kun to demokratiske, stuerene regeringer, Senegal og Niger. Senegal, det land der længst havde været nært knyttet til Frankrig, var mest præget af fransk kultur. Det havde en lang tradition for militært samarbejde med Frankrig. Senegalesiske tropper havde kæmpet på Vestfronten under Første Verdenskrig og været med i krigen i Algeriet 1954-62.

Det blev da også i Dakar, François Hollande den 12. oktober for første gang formulerede sin afrikanske politik. Han anførte først åbenhed. "Vi skal sige alt til hinanden, uden indblanding, men også åbenhjertigt", sagde han. Hvad han mente hermed, understregede han dagen efter på det frankofone topmøde i Kinshasa. Han gav de diktatorer, der var ved magten takket være hans forgængere, den kolde skulder, mens han gjorde stads af Nigers regulært valgte præsident Mahamadou Issoufou. Det var også i Niger, Frankrig havde sine væsentligste $ø$ konomiske interesser, uranminerne, som var med til at forsyne atomindustrien med brændstof.
I Dakar understregede Hollande videre, at problemerne skulle tackles multilateralt, ikke bilateralt. "Afrikas fremtid skal bygges på en styrkelse af afrikanernes evne til at styre deres egne kriser", sagde han videre.

Hollande var her på linje med den politik, som regeringen Lionel Jospin havde søgt at føre under præsident Chirac og for alvor ville føre ud i livet, hvis Jospin vandt præsidentvalget i 2002. Men det gjorde han mod al forventning ikke. Han blev slået på andenpladsen i første runde af Jean-Marie Le Pen.

På mødet i Kinshasa den 13. oktober 2012 var der en diktator, der diskret havde meldt afbud på grund af sygdom, så han ikke kunne møde op for at få den kolde skulder. Han var fra Tchad, og havde siddet der, siden Mitterrands dage som præsident.

\section{Mitterrands særlige rolle}

Ingen fransk præsident havde haft så nært og personligt et forhold til det sorte Afrika som François Mitterrand, der sad på posten i fjorten år. Da han ved krigsudbruddet i 1939 blev indkaldt, blev han på grund af sin kritiske holdning til den måde, den franske hær forberedte sig på opgøret mod Nazityskland, sat til at være sergent i et senegalesisk regiment. Da det gik løs i maj 1940, blev han oprørt over at opleve, hvordan de sorte soldater hensynsløst blev brugt som kanonføde. 
Mitterrand blev selv såret og efterladt på en båre af sygepasserne på en landevej under et tysk styrtbombeangreb og derpå taget til fange. Han forsøgte tre gange at flygte. Efter halvandet år lykkedes det tredje gang. Han slap til Frankrig, hvor han opbyggede sin egen modstandsorganisation. Efter befrielsen følte han sig ikke hjemme i nogen af de gamle partier, som nu dukkede frem igen.

I samme situation befandt en mand sig, der havde spillet en vigtig rolle på udefronten i den frie franske modstand mod Vichy-regeringen, ikke mindst i Afrika. Han hed René Pleven. Men ikke mange havde hørt om ham. Han havde i mange år været ansat i Jean Monnets internationale investeringsfirma. Monnet havde under Første Verdenskrig som fransk repræsentant i London ydet et banebrydende bidrag i kampen mod tyskernes uindskrænkede ubådskrig ved at foreslå oprettelse af en fælles tonnagepulje. Ingen havde nu bedre forbindelser i London og Washington end Monnet.

Da fronten i Frankrig brød sammen i 1940, var Pleven med til at organisere den bro af både, der reddede først de britiske tropper, derpå en del af de franske, der var omringet i Dunkerque, over til England. Han hjalp på den måde en ensom de Gaulle til at få oprettet den første frie franske hær og flåde efter det sidste møde i den franske regering, som han var blevet optaget i som be- lønning for to gange at have standset tyskerne.

Kun et andet medlem af regeringen havde været imod at give op. Det var koloniminister Georges Mandel. Han blev derfor opfordret til også at komme til London for at danne en eksilregering ligesom nordmændene. Han havde været Georges Clemenceaus højre hånd under Første Verdenskrig i de afgørende år 1917-18. Han vaklede. Han handlede. Hans holdning var i 'Tigerens' ånd. Men han vaklede, fordi han var jøde. Han ville ved at forlade landet give stof til den antisemitiske hetz, der omgående brød løs, da anti-Dreyfusarderne vendte tilbage til magten under marskal Pétain.

Kort inden Paris' befrielse i 1944 blev han myrdet ved et clearingsmord af franske fascister i Fontainebleau Skoven.

Mandel havde også handlet i Clemenceaus ånd, da han som koloniminister i 1938 havde udnævnt den første neger, Felix Eboué til guvernør i Afrika. Det blev i Tchad. For Clemenceau havde energisk bekæmpet den franske kolonipolitik i imperialismens tidsalder, da den ville aflede opmærksomheden fra 'Vogesernes blå synsrand'. Eboué handlede i Mandels ånd, da han i august 1940 blev den første, der sluttede et fransk område til de Gaulle.

Generalen sendte Pleven til Ækvatorialafrika som sin repræsentant. Måske også, fordi han stammede fra Bretagne. 


\section{På 12 millioners vegne}

I Nordfrankrig, som de Gaulle kom fra, interesserede man sig ikke så meget for kolonier. Selv forsøgte generalen en landgang i Dakar i Vestafrika i september 1940. Den mislykkedes, og han måtte dybt nedbøjet ty til Ækvatorialafrika, hvor den uforstyrrelige Pleven gav ham nyt mod til at fortsætte. Han kunne nu tale på ' 12 millioners vegne'.

Der blev organiseret en fri fransk styrke i Tchad, som grænsede op til det italienske Libyen. Under kommando af en ung officer, der skønt såret havde været blandt de første, der sluttede sig til de Gaulle i London. Han hed Leclerc og anførte de første indfald i Libyen. Det gik efterhånden så ilde her for italienerne, at Hitler måtte oprette et særligt Afrikakorps under general Erwin

Rommel. Han lancerede i maj 1942 en lynoffensiv, der sigtede mod Kairo. Men han blev forsinket undervejs, bl.a. af en fransk brigade, der var kommet op fra Tchad og ydede forbitret modstand ved Bir Hakeim. Det blev de frie franskes første militære triumf, som for alvor vakte international opmærksomhed.

To år efter blev det general Leclercs Anden Franske Panserdivision, der først rykkede ind i Paris og modtog byens overgivelse.

Men i mellemtiden havde Felix Eboué arbejdet med planer for, hvordan de fremtidige franske statssamfund skulle være. De blev fore- lagt på en 'imperiekonference' i Brazzaville i januar 1944, organiseret af Pleven. De Gaulle sammenfattede resultatet i en tale, hvori han sagde: "I det franske Afrika og andre steder, hvor mennesker lever under vort flag, vil der ikke være noget virkeligt fremskridt, hvis de ikke efterhånden kommer op på et niveau, hvor de bliver i stand til at deltage $\mathrm{i}$ ordningen af deres egne anliggender." Efterhånden som de gamle politikere igen dukkede op, fandt Pleven og Mitterrand hinanden i et forsøg på at få dannet et parti, der kunne repræsentere modstandsbevægelsen. De kaldte det Union Démocratique et Socialiste de la Résistance (UDSR).

Den socialist, der havde været partiets store håb, Pierre Brossolette, havde taget sig af dage, da han faldt i Gestapos hænder, så partiet igen havde måttet ty til den nu 73-årige Léon Blum, da han vendte hjem fra en internering i Tyskland. Trods det pompøse 'Union'fik UDSR kun 31 mandater ved det første valg efter krigen. Men under de parlamentariske forhold, der opstod i den Fjerde Republik, hvor 'den tredje styrke' fra 1947 kom til at manøvrere mellem kommunister og den gaullistiske Fransk Folkesamling (RPF), blev det tungen på vægtskålen. Mitterrand kom efterhånden til at overtage det ene ministerium efter det andet. Men Pleven vakte hans interesse for Afrika, som han blev stærkt optaget af under sit første besøg. Da pre- 
mierministerrouletten i juli 1950 standsede ved Pleven, gjorde han Mitterrand til minister for det oversøiske Frankrig, dvs. Afrika. Mitterrand fik nu for alvor indsigt i forholdene i kolonierne og blev rystet over den behandling, de sorte fik af kolonisterne med tvangsarbejde, underbetaling og korporlig afstraffelse. De snød bønderne på vægten, når de aftog deres kaffebønder.

Mitterrand udarbejdede et reformprogram for omdannelse af den Franske Union til et forbund af demokratiske stater. Han støttede sig især til Elfenbenskystens repræsentant i den franske nationalforsamling, Houphouet-Boigny, der i 1946 havde været med til i Bamako at grundlægge det første afrikanske parti Rassemblement Démocratique Africain, som han blev formand for. Han forlod nu den kommunistiske gruppe i Nationalforsamlingen for at tilslutte sig Plevens og Mitterrands UDSR.

Men Plevens regering blev snart styrtet. Indokina blev det dominerende problem, indtil det i 1954 lykkedes Mendès France at få fred på grundlag af en tostatsløsning, et kommunistisk Nordvietnam og et Sydvietnam, der blev domineret af vietnamesiske katolikker. Da Japan i 1600-tallet udviste de kristne missionærer, havde de søgt tilflugt i Indokina.

Men snart blev Mendès France styrtet, og den europæiske befolkning i Algeriet fik Frankrig trukket ind i en ny krig, der efterhånden førte til, at en hær på over 400.000 mand blev stationeret i Nordafrika uden at kunne få kuet løsrivelsesbevægelsen FLN. De Gaulle blev kaldt tilbage til magten. Han fik nu lejlighed til at føre sine tanker fra Brazzaville ud i livet. Men tiden var løbet fra dem. Der var opstået en ny 'tredje verden'. I Afrika syd for Sahara krævede de fransksprogede stater forskellige grader af selvstændighed, og i Algeriet måtte man i 1962 afslutte krigen med en fjendtlig ny stat og en masseflugt af europæere til Frankrig.

Samtidig med, at de Gaulle selv faldt i 1969 efter et indre ungdomsoprør, trådte en ny uforudsigelig og ambitiøs aktør ind på scenen i Afrika med oberst Gaddafis kup i Libyen. Han havde bl.a. territorialkrav i Tchad, og i 1976 indgik Jacques Chirac som premierminister under præsident Giscard d'Estaing på Frankrigs vegne en aftale med Tchads regering om fransk bistand i uddannelsen af dens hær.

Da Mitterrand i 1981 omsider kom til magten i Paris, havde han ikke glemt afrikanerne. Han fejrede sejren ved en højtidelig ceremoni, hvor han lagde tre røde roser på tre sarkofager i Republikkens verdslige gravkirke Panthéon. Den røde rose var blevet socialisternes partimærke. De tre mænd, han hyldede på denne måde, var det franske socialistpartis grundlægger Jean Jaurès, der blev skudt dagen før krigsudbruddet 
i 1914. Jean Moulin, den første formand for frihedsrådet under besættelsen, der blev myrdet af Gestapo. Victor Schoelcher, der i 1948 havde afskaffet negerslaveriet i fransk Vestindien. I 1949 var også Felix Eboué, der var død i Kairo i maj 1944, blevet gravsat i Panthéon, af en regering, hvori Mitterrand var informationsminister og især gjorde sig bemærket ved at oprette filmfestivalen i Cannes.

I mellemtiden havde Mitterrand affundet sig med, at hans afrikanske venner flere steder havde udviklet sig til at blive en slags enevældige patriarker, der regerede ved livgarder, valgfusk, nepotisme og korruption samtidig med, at de som Houphouet Boigny slog sig på storslået prestigebyggeri.

\section{Gorbatjov skaber røre}

Men i hele det fransksprogede Afrika vakte Gorbatjovs politik i Østeuropa, der førte til Murens fald i 1989 , røre. En del af den yngre generation i det franske Socialistparti mente derfor, at Mitterrand havde slået sig lidt for meget til tåls med de afrikanske diktatorer. Det var på tide at finde hans program fra 1950 frem af skuffen og gøre noget for demokratiet. Det blev til en programerklæring på en konference i La Baule i 1990 og et forsøg på at få indført demokrati i Togo, der havde et af de mest diktatoriske regimer. En ny, mere demokratisk regering, blev dog snart væltet ved et kup, og Mitterrand afviste at gribe ind med henvisning til, at man ikke skulle blande sig i andre landes indre anliggender.

Da Saddam Hussein i Irak i sommeren 1990 invaderede Kuwait, reagerede USA kraftigt og knuste i begyndelsen af 1991 i løbet af 100 dage den irakiske hær med Thunderstorm, der især kom fra luften. Det skete under den første sorte forsvarsminister i USA, Colin Powell, og for første gang modsatte Sovjetunionen under Gorbatjov sig ikke den amerikanske politik i FN.

I Libyen fandt oberst Gaddafi det nu klogest at lægge roret om. Han støttede en ung officer, der havde fået sin uddannelse som pilot $\mathrm{i}$ Frankrig, Idriss Déby, da denne i 1990 greb magten i Tchad og lovede at tillade valg med flere partier. Gaddafi accepterede også et fransk forslag om at lade grænsestriden mellem Libyen og Tchad afgøre ved den internationale domstol i Haag, og da dommen gik ham imod, trak han i foråret 1994 sine tropper ud af det nordlige Libyen. Det blev en triumf for den politik, som Mitterrand var slået ind på, da han med Mantraoperationen i 1983 sendte franske tropper til Tchad for at adskille den libysk besatte muslimske nordlige del af landet fra de sorte provinser i syd. I mellemtiden havde ydre trusler fra Sudan og indre oprør fået Déby til indtil videre at lægge demokratiseringen på hylden. Men der 
blev omsider skabt en vis stabilitet i det urolige land.

Da Jean Lacouture i arbejdet med sin store Mitterrand biografi kort inden hans død af en langvarig kræftsygdom, spurgte ham, hvad han selv anså for sin største politiske indsats, henviste han til Afrika. Da den ny generation med Lionel Jospin kom til at danne regering i januar 1997, var Chirac præsident, og premierministerens muligheder var begrænsede. Chirac kendte Nordafrika fra sin tid som officer i Algeriet under krigen. Da Sarkozy afløste Chirac i 2007 havde Gaddafi manøvreret sig ind i et så afspændt forhold til den vestlige verden, at han blev inviteret til Paris, hvor han fik lov til at slå sit beduintelt op og medbringe sine kameler. Først med Hollandes sejr i 2012, blev socialisterne igen ene om at fastlægge den franske politik i Afrika.

Hollande havde selv et vist førstehånds kendskab til Afrika. Han havde valgt at blive udstationeret i Algeriet som led i sin uddannelse på den franske magtelites foretrukne læreanstalt, forvaltningshøjskolen Ecole Nationale d'Administration, som de Gaulle havde fået oprettet efter befrielsen i 1944 for at få uddannet embedsmænd, der ikke havde deltaget i Vichy-regeringens samarbejdspolitik under besættelsen.

Men når det drejede sig om Vestog Ækvatorialafrika, kunne han først og fremmest stole på sin nære ven fra soldatertiden, forsvarsminister
Jean-Yves Le Drian. Som borgmester i den store orlogshavn Lorient havde han god indsigt i forholdene i denne del af Afrika, hvor Frankrig havde godt 5.000 soldater udstationeret fra marineinfanteriet, 'marsvinene', og fremmedlegionen efter aftaler med staterne Senegal, Elfenbenskysten, Tchad og Gabon samt senere den Centralafrikanske Republik.

Fremmedlegionen var oprindeligt blevet oprettet for at bekæmpe indfødte oprørere i Algeriet. Man havde navnlig haft besvær med Abd el Kader, som Karen Blixens fader, Adolph Dinesen, var med til at bekæmpe, men bagefter skrev en beundrende bog om. Det indgik i Fremmedlegionens fundats, at den aldrig måtte stationeres i selve Frankrig, så den kunne bruges i indre magtkampe. Efter at Algeriet var blevet selvstændigt, måtte den derfor flyttes til andre steder i Afrika.

Men Hollande aflagde et besøg i Algeriet i december 2012 for at forbedre forholdene til regeringen i Algier, der selv havde haft store problemer med islamisterne. Han opnåede her en tilladelse til fransk overflyvning, hvis det skulle blive nødvendigt at gribe til våben i Mali. Den skulle snart vise sig at blive afgørende.

Da AQIM i begyndelsen af 2013 havde samlet en styrke, der kunne erobre Bamako, blev Frankrig fra flere sider opfordret til at gribe ind, men fik kun få tilsagn om støtte. 
Især var man i Paris skuffet over Tysklands reaktion, mens Danmark sjældent er blevet så hyppigt omtalt i fransk radio og tv. Hollande fik bred tilslutning i Frankrig, da han den 11. januar besluttede at sætte flyvevåbenet ind mod den $\mathrm{AQIM-kolon-}$ ne, der rullede mod Bamako. To-tre dage senere ville det have været for sent, sagde den franske forsvarsminister bagefter.

Tilbage stod den opgave at rense Nordmali for terrorister. Selv om der ikke kom nogen hjælp fra det MISMA-korps, som vestafrikanerne havde besluttet at oprette, og der ikke var meget tilbage af Malis egen hær, lykkedes det ret hurtigt at erobre de vigtigste byer i nord, hvor de franske styrker blev modtaget som befriere, da jihadisterne simpelthen flygtede til det vanskeligt tilgængelige bjergområde Ifoghas. Hollande selv kunne aflægge et besøg i Mali, hvor han fik en begejstret hyldest af befolkningen i både Bamako og de erobrede nordlige byer. Men tilbage stod den langt vanskeligere opgave at erobre selve bjerglandet, der med kratskove og klippehuler var ideelt snaphaneland.

Da det kom til stykket, hvor man skulle prøve at få kontrol med AQIM's bjergland, var det kun Tchad, der kunne stille op. Déby havde opbygget en hær på 30.000 mand for at afværge ydre trusler fra Libyen og Sudan, som Mitterrand havde hjulpet ham imod 20 år før. Han afviste at have noget med
MISMA at gøre, men sendte et korps på 4.000 mand rekrutteret fra hans egen stamme og sin søn. De havde en erfaring fra samarbejde med de franske tropper, der var stationeret i landet, kendte terræn af den type, der skulle kæmpes i, og skulle vise sig at være nogle effektive forbundsfæller.

Når det gjaldt indsats mod en guerillastyrke, vidste franskmændene fra Afghanistan, at det vigtigste var information og overrumpling. Det lykkedes over forventning. En offensiv mod terroristernes hovedkvarter, klippefæstningen i Tigharghar-højlandet blev indledt den 18. februar. Den 2. marts kunne chefen for det tchadianske korps meddele, at han havde haft de første sammenstød med jihadisterne, og at deres to mest frygtede høvdinge Abou Zeid og Mokhtar Belmokhtar (den enøjede), var blevet dræbt.

500 franske marineinfanterister og paras, faldskærmssoldater, sammen med 1.200 tchadianere havde erobret, hvad der blev betegnet som AQIMs hovedfæstning. Det kom åbenbart bag på jihadisterne, at franske soldater kunne bevæge sig i terrænet og slås med en oppakning på $40 \mathrm{~kg}$ i over 40 graders varme, tilmed uden at få noget videre at spise i to-tre dage.

Til sammenligning med tidligere operationer i Algeriet rådede de imidlertid nu over kamphelikoptere og droner, der kunne anvendes til både opklaring og præcisionsslag. 
Desuden havde de muligheder for at hacke sig ind på de moderne kommunikationsmidler, som jihadisterne rådede over. Man slap dog ikke for mand til mand opgør til dels i mørke klippegange under jorden. For ikke bare var selve hovedkvarteret underjordisk, så det kunne modstå luftangreb. Det var også forsynet med fremskudte nedgravede forter. En del af jihadisterne flygtede for at gemme sig i befolkningen, som de havde gjort i Afghanistan. Andre kæmpede til de faldt, og tchadianerne havde væsentligt større tab end de franske tropper, der kun oplevede to dræbte. Men der blev ikke taget mange fanger. Det viste sig snart, at nogle af dem, der strakte hænderne i vejret for at overgive sig, sprængte sig selv i luften, når de kom tæt nok på til at kunne tage andre med sig i døden. Adskillige af dem var kun store drenge.

Franskmændene blev forbløffede over, hvad de fandt, da de havde erobret fæstningen. Lagre med snesevis af ton af våben og ammunition. Der var fødevarer og vand til en langvarig belejring. Men bedst af alt et omfattende udstyr af computere og kommunikationsudstyr med telefonnumre og adresser ikke bare i Sahel området, men også i Europa lækkerier for efterretningsvæsenet.

Der var også laboratorier til fremstilling af bomber og i tilknytning til fæstningen en træningslejr til uddannelse af jihadister, som man nu stadig oftere kaldte terrorister.
Da forsvarsminister Le Drian besøgte soldaterne efter to måneders krig, erklærede han dog, at man endnu ikke var ved vejs ende, kun 70 pct. af vejen. Der stod endnu en vanskeligt tilgængelig del af Mali tilbage at få kontrol med, og den tid nærmede sig, hvor militære operationer ville blive umulige på grund af regn og hede. Det skulle også snart vise sig, at terroristerne stadig kunne gøre skade med attentater og vejsidebomber.

\section{Hessels død}

Hollande fik efter Tigharghar-sejren en uventet lejlighed til at markere, at han så sin indsats mod AQIM som en fortsættelse af modstandsbevægelsens kamp mod fascismen, da en af Résistancens mest lysende skikkelser, Stéphane Hessel, afgik ved døden, netop som hans nye bog, en fortsættelse af Indignez-vous!, der var blevet en bestseller solgt i fire millioner eksemplarer i hele verden, kom i handelen. Engagez-vous! hed bogen meget passende til situationen.

Hessel var af tysk oprindelse, men meldte sig ligesom Pierre Mendès France til de Gaulles frie franske flyvevåben i England. Han blev i foråret 1944 sat i land i Frankrig for at opbygge et efterretningsnet. Han blev taget af Gestapo kort før Paris' befrielse og ført til koncentrationslejren Buchenwald. Hessel overlevede, mente han selv, ved hver aften at holde modet oppe ved at citere ty- 
ske og franske digte for sig selv.

Endnu nogle uger inden Hessels død i en alder af 95 år kunne man høre ham i tysk radio citere et langt digt af Rainer Maria Rilke med gammelmandsstemme, men uden at tøve. Af franske digtere var Apolinaire, som bestemt ikke er let at huske, hans foretrukne. Da Mendès France dannede regering i 1954, blev Hessel hans højre hånd. Men ellers blev hans videre løbebane på det diplomatiske felt især inden for FN's menneskeretsarbejde.

\section{Befriere, besættere}

Hessels sidste budskab til de unge blev, at de skulle engagere sig med de unge i verdens fattige lande for at få ændret den hidtidige bistandspolitik til en strategi, der sigter mod bæredygtig udvikling, som ville gavne disse lande mere end de rige. I FN burde man oprette et sikkerhedsråd for økonomisk og social udvikling, der ikke bare repræsenterer G-20 landenes interesser.

Hollande holdt den ene af hovedtalerne for ham, da han blev hyldet ved en storslået militær mindehøjtidelighed i Invalidehotellets gård.

Men Hollande vidste også, bl.a. fra Afghanistan, at fremmede soldater, selv om de kommer som befriere, efter tre måneder, begynder at blive betragtet som besættere. Han lagde derfor vægt på, at franske tropper skulle begynde at forlade Mali i april, og holdt fast ved sit standpunkt fra Dakar, at opretholdelsen af freden i Mali skulle internationaliseres, overtages af FN-tropper, fortrinsvis afrikanske blå hjelme, der dog nok måtte have et mere 'robust mandat', end fredsbevarende FN-tropper sædvanligvis har. Afhængig af hvordan det ville gå med den vanskelige opgave at få genopbygget en stat i Mali, der kunne fungere, opretholde ro og orden og opfylde Hollandes andet mål, at det blev et demokratisk land.

Udsigterne var ikke umiddelbart de bedste. Hvor maliske tropper deltog i erobringen af AQIM-området, fik de især til opgave at opretholde ordenen i de befriede byer. De forfaldt undertiden til misbrug af den opgave ved at hæune sig på formodede islamistiske samarbejdsfolk. Kupkaptajn Sanogo var blevet i Bamako, hvor han stadig fra kulisserne bestemte, hvem der kunne accepteres i en overgangsregering, og greb ind mod pressen, hvis den kritiserede ham.

Ellers var de afrikanske journalister nok de bedste støtter for demokratiet. Med dygtig og modig kulegravende journalistik var de på vagt mod magtmisbrug og korruption. Kunne de ikke komme til orde i deres egne lande, havde de adgang til de afrikanske udsendelser i Radio France Internationale, der utvivlsomt må være stærkt aflyttet af den omfattende fransksprogede kulturelite i Afrika. Efterhånden regner man med, at den fransksprogede verden 
omfatter 220 millioner. Også nyhedsmagasinet Jeune Afrique, der redigeres af afrikanere i Frankrig, ligger på et højt niveau og holder godt øje med, hvad der sker i Afrika. Det lægger ikke fingrene imellem.

Men at det vil blive en langvarig proces at få oprettet en demokratisk stat i Mali, er oplagt. Da Tyskland omsider gik med til i hvert fald at deltage i opbygningen af en ny hær, erklærede forsvarsminister de Mézières, at man måtte regne med mindst et år. Hollande har optimistisk erklæret, at de franske tropper i Mali i slutningen af juli vil blive reduceret fra 4.000 til 2.000 mand og ved årets udgang være nedskåret til 1.000 , samt at de efterhånden vil indgå i en FN-styrke.

En afgørende prøve blev i første omgang afholdelse af præsidentvalg. Der blev nedsat en kommission til forberedelse af et valg i juli. Men nogen oplagt kandidat var ikke i syne, og nogle oppositionspolitikere tøvede med at vende hjem. Mange frygtede, at Sanogo helt ville gribe magten, når de franske tropper er trukket tilbage.

Men det var klart, at Afrikas toneangivende politiker fra nu af ville blive Tchads præsident Idriss Déby Itno, ikke bare på grund af hans militære bedrifter i Mali, men i lige så høj grad ved de diplomatiske indsatser, han havde gjort inden. Han havde fået nyt liv i den omfattende afrikanske Cen-Sad organisation, der strakte sig fra Marokko til Det Røde Hav. Det lykkedes ham at samle 24 af dens 28 medlemsstater til et topmøde i februar 2013 i hovedstaden N'Djamena, hvor de vedtog en ny traktat om sikkerhed og økonomisk samarbejde. I forvejen havde han optrådt som mægler i flere afrikanske stater, hvor der var konflikter mellem selvherskere og oppositionen. I selve Tchad var der et vist spillerum for oppositionen, der til gengæld sluttede op bag præsidenten i kampen mod AQIM i Mali. "Terroristerne kender ingen grænser", erklærede han. "Det kan ryge op i fjæset på én (vous sauter à la gueule), hvor som helst og når som helst". Det gjaldt derfor om at arbejde sammen. Han ville selv helst kaldes 'fredspræsidenten' og satsede på at komme til at repræsentere Afrika i FN's sikkerhedsråd fra efteråret 2013. Som under Felix Eboué i 1940 var det igen Tchad, der tog føringen.

Denise Séheux er tidligere sekreter i det franske finansministerium og assistent $i$ årtier for egtemanden Erling Bjøl, dr.scient.pol, professor emeritus. 